\title{
Eksistensi KPK dalam Peradilan Korupsi di Indonesia
}

\author{
M. Abdul Kholiq, AF
}

\begin{abstract}
'
The existence of KPK based on the act No. 30/2002 is aimed to be special super body organization to optimize in wiping out corruption in Indonesia. The special features are: . caused first the institution of law upholder existed (c.c police and attomey) is dependent instifutionally because of the position is under the executive (c.q President); second, the action of law enforcement for the corruption criminal by both institution tend to show their recklessness. In other words; it is not effective, efficient and optimal and it has bom 'pessimistic for the public as well about law supremacy, especially in wiping out the corruption practices. To enhance the public trust as well as the prestige of KPK itself, so KPK must wipe out the corruption practices continuously without any compromising but is must be suitable with the fask and authority given by legislation.
\end{abstract}

\section{Pendahuluan}

Bagi Indonesia; kejahatan korupsi sepertinya telah ditakdirkan sebagai problem sosial yang seakan tidak pernah habis untuk dibahas. Berbagai komponen bangsa mulai dari kalangan masyarakat yang populer disebut "wong cilik" hingga orang-orang yang berkategori "top lever", apapun alasan dan tujuannya , seolah merasa absah .untuk membicarakan korupsi atau minimal memprihatinkannya.'

Jika dikkaitkan dengan fakta mengenài realitas korupśi di Indoriesiá, maka perhatian serta keprihatinan publik di atas tampaknya memang beralasañ. Sebab koridisi kejahatan korupsi yang terjadi di Indonesia dewasa ini kenyataannya memang sudah sangat keterlaluan. Fenomena legislatif corruption yaitu prakték korupsi oleh kalangan wakil

${ }^{\mathfrak{t}}$ Menurut hasil tracking survey Intermational Foundation for Election System, masalah korupsi.dan penanggulangannya ternyata menjadi isu yang paling dipilih oleh partai maupun para capres-cawapres dalam kampanye Pemilu 2004 ini, yaitu sekitar $30 \%$. Tujuannya tak lain adalah untuk menarik simpati publik. Diangkatnya isu ini tampaknya telah mengalahkan isu-isu penting lainnya seperti perbaikan ekonomi makro, penciptaan lapangan kerja dan sebagainya. Baca selengkapnya mengenai hal ini pada tulisan Teten Masduki, Retorika - Antikorupsi Capres, dalam harian Kompas edisi tanggal 12 Juni 2004. 
rakyat (c.q DPRD) di sejumlah daerah yang marak diberitakan media massa akhir-akhir ini, barangkali dapat menjadi suatu indikator yang relevan untuk dikemukakan. Sebab sebagai wakil rakyat seharusnya mereka menjalankan salah satu fungsi pokoknya yakni mengontrol jalannya pemerintahan agar tercipta good and clean govemance. Bukan malah sebaliknya yakni mempersubur pemerintahan dan kehidupan bangsa yang korup.

Selain itu, parahnya keadaan korujsi di Indonesia antara lain juga dapat ditunjukkan melalui indikator tentang pemeringkatan negara-negara koruptor di dunia. Dalam hubungan ini, menurut lembaga riset Transparency International (TI), tahun 1995 indonesia dilaporkan berada diperingkat pertama dalam urutan negara terkorup di dunia. Laporan serupa pada tahun 1998 (sebagai tahun awal reformasi) menyebutkan Indonesia berada di posisi keenam. Kemudian sampai pada tahun 2003 yang lalu (artinya lima tahun setelah reformasi berjalan), ternyata kondisi masalah korupsi di Indone- sia pun tidak ada perubahan sama sekali. Karena TI masih melaporkan negara ini sebagai terkorup keenam di dunia. Ini berarti kehadiran reformasi dengan upaya pemberantasan korupsi seolah tidak ada korelasi. Betapa pun semua elemen bangsa tentu paham bahwa pemberantasan Korupsi, Kolusi dan Nepotisme (KKN) adalah merupakan salah satu butir penting di antara enam agenda pokok gerakan reformasi yang telah menjadi konsensus nasional.

Sebenamya berbagai ide atau pemikiran untuk menanggulangi korupsi di Indonesia sudah banyak dan terus menerus diwacanakan oleh beragam kelompok masyarakat. Bahkan sebagian di antaranya pun sudah ada yang menjadi langkah atau kebijakan kongkrit pemerintahan. ${ }^{2}$.

Namun, persoalan korupsi di Indonesia tampaknya memang harus mulai disadari oleh siapa pun bahwa ia bukan lagi sekedar problem tentang besarnya jumlah kerugian keuangan negara, atau modus operandi koruptor yang semakin canggih, peringkat Indonesia yang selalu menempati kelompok

2 ide tentang perlunya diterapkan asas pembuktian terbalik dalam penanganan kasus korupsi misalnya, sekarang inipun sudah menjadi hukum positif dalam UU No. 31 Tahun 1999 jo. UU No. 20 Tahun 2001 walaupun tidak bersifat pembutian terbalik mumi. Mengenai hal ini selengkapnya dapat dibaca M. Abdul Kholia, Asas Pembüktian Terbalik dalam Penyelesaian Kasus Kejahatain Konupsi, artikel pada'Jumal Hukumedisi No. 20 Volume 9 Tahun 2002, hlm. 55-67. Dalam ranah gerakan moral, bentuk-bentuk sikap antikorupsi pun sudah banyak dikumandangkan oleh berbagai kalangan. Sebut saja misalnya NU dan Muhammdiyah sebagai dua ormas terbesar di Indonesia pada tanggal 15 Oktober 2003 telah mendeklarasikan dan menanda tangani Memorandum of Understanding (MoU) tentang gerakan kultural memerangi konupsi. Pada tanggal 16 Desember 2003, Kadin dan sejumlah LSM pun telah melakukan penanda tanganan dengan pemerintah yang diwakili Menteri Pendayagunaan Äparatur Negara (PAN) mengenai Gerakan Anti Suap dalam dunia usaha. Terakhir; dalam kancah internasional, pada tanggal 18 Desember 2003 pemerintah Indonesia juga telah meletakkan suatu landasan moral untuk kerjasama di antara berbagai negara dalam berperang melawan korupsi yang ternyata punya dimensi sebagai trans national crime dengan menandatangani Konvensi PBB tantang Pemberantasan Korupsi atau United Nations Convention Against Corruption di New York, USA. 
sepuluh besar sebagai negara terkorup di dunia ataupun problem perundang-undangan yang sebenarnya sudah cukup memadai.

Di era keterbukaan ini terkuak suatu kenyataan bahwa sulitnya memberantas korupsi di Indonesia adalah diakibatkan juga karena ketidak berdayaan aparatur penegak hukum dalam menghadapi kasus tindak pidana korupsi. Sebab mereka sendiri sering kali justru terindikasi terlibat KKN dalam menjalankan tugas-tugasnya.

Ada sejumlah fenomena dalam praktek penegakan hukum terhadap kejahatan korupsi yang menarik untuk dicermati dalam rangka memperjelas indikasi keterlibatan aparat tersebut. Pertama, melalui media massa seringkali ditemukan adanya beberapa kasus korupsi besar yang tidak pernah jelas ujung akhir penanganannya. Kedua, pada kasus tertentu juga sering terjadi adanya kebijakan pengeluaran SP-3 (Surat Perintah Penghentian Penyidikan) oleh aparat terkait sekalipun bukti awal secara yuridis dalam kasus tersebut sesungguhnya cukup kuat. Ketiga, kalaupun suatu kasus korupsi penanganannya sudah sampai di persidangan pengadilan, seringkali publik dikejutkan bahkan dikecewakan oleh adanya vonis-vonis yang melawan arus dan rasa keadilan masyarakat.

Berdasarkan fenomena mengenai kualitas penegakan hukum di atas, maka pemerintah dengan desakan kekuatan kontrol dari masyarakat menegaskan kesadaran bahwa penanganan kejahatan seriušs : seperti korupsi tidak cukup jika hanya mengandalkan peran dan kinerja aparat penegak hukum konvensional. Ada semacam kebutuhan terhadap hadirnya suatu lembaga independen baru yang dapat meningkatkan daya fungsi lembaga-lembaga penegak hukum yang sudah ada selama ini dan badan-badan lain yang terkait dalam penanganan perkara tindak pidana korupsi.

Stagnasi atau bahkan kemunduran penegakan hukum terhadap KKN dalam kurun lima tahun era reformasi, tampaknya telah menjadikan masyarakat Indonesia sudah tidak sabar lagi mendengar berbagai alasan klasik dari aparat yang menangani kasus-kasus tersebut. Selama ini, jika kepada hakim diajukan pertanyaan "bagaimanakah ujung akhir tentang penyelesaian berbagai kasus korupsi yang sempat menjadi perhatian publik?" Pada umumnya hakim menjawab: "kami belum menerima limpahan perkara dari Penuntut Umum". Sementara Penuntut Umum pasti akan menjawab pula bahwa mereka juga belum menerima-limpahan perkara dari Penyidik. Selanjutnya penyidik pun biasanya akan lancar mengemukakan berbagai alasan mengapa pihaknya harus menunda pengajuan perkara ke Penuntut Umum. Misalnya karena ada kesulitan membuktikan unsur kerugian negara, belum terpenuhinya bukti awal hukum yang cukup, belum adanya izin pemeriksaan dari Presiden jika menyangkut tersangka yang merupakan seorang pejabat negara dan lain sebagainya. ${ }^{3}$

${ }^{3}$ Problem harus adanya izin Presiden untuk dapat memeriksa pejabat negara baik eksekutif maupun legislatif saat diduga terlibat tindak pidana korupsi, antara lain dapat dicermati paoa kasus mutakhir seperti Abdullah Puteh, Nurdin Khalid dan sebagainya. Keharusan izin di atas kenyataannya memang seringkali dimanfaatkan para tersangka untuk menghindar dari pemeriksaan aparat. Namun demikian tidak sepantasnya jika aparat juga berlindung dibalik problem ini untuk kemudian tidak pro aktif melakukan pengusutan suatu perkara yang memang menjadi tugas dan kewajibannya. 
Argumentasi-argumentasi semacam tersebut di atas sesungguhnya mencerminkan ketidak berdayaan sub-sub sistem dari sistem peradilan pidana yang ada dalam menyelesaikan kasus korupsi. Oleh karena itu wajar jika pada akhirnya muncul desakan mengenai perlunya suatu badan khusus mandiri (super body) yaing dapat bekerja secara multi disiplin dengan kewenangan dan kemampuan untuk mengambil alih tugas dan fungsi penyelidikan, penyidikan dan penuntutan terhadap tindak pidana korupsi yang terindikasi "macet" atau sengaja "dimacetkan" oleh aparat konvensional.

Dalam perspektif sejarah perkembangan penanganan korupsi di Indonesia, realisasi ide tentang pembentukan badan khusus tersebut sesungguhnya sudah beberapa kali diupayakan. Misalnya dibentuknya Komisi Ombudsman beberapa tahun lalu yang spesifik bertugas mengakomodir pengaduan masyarakat yang hendak melaporkan indikasi telah terjadinya suatu tindak pidana korupsi. Didirikannya Komisi Pemeriksa Kekayaan Pejabat Negara (KPKPN) dengan tugas utama auditing harta pejabat untuk tujuan prevention of corruption. Atau dibentuknya Tim Gabungan Pemberantasan Tindak Pidana Korupsi (TGPTPK) berdasarkan PP No.19 Tahun 2000 yang merupakan realisasi amanat UU No. 31 Tahun 1999 tentang Korupsi.
Namun dengan asumsi karena keterbatasan kewenangan maka kinerja badan-badan khusus tersebut pun dalam kenyataan tidak memperlihatkan hasil yang maksimal. Oleh karena itu pemerintah dan DPR pada tanggal 27 Desember 2002 melalui UU No. 30 Tahun 2002 telah sepakat dan mensahkan hadirnya institusi baru dalam peradilan korupsi di Indonesia yang diberi nama resmi Komisi Pemberantasan Tindak Pidana Korupsi (KPTPK) atau populer dengan sebutan Komisi Pemberantasan Korupsi (KPK

Eksistensi lembaga super body semacam KPK di atas, sebenarnya tidak sama sekali merupakan hal yang aneh dalam optik Sistem Peradilan Pidana. Secara komparatif, lembaga serupa juga dapat dijumpai di beberapa negara tetangga. ${ }^{4}$ Bahkan negara maju seperti Amerika Serikat yang memiliki pendukung sub sistem peradilan pidana yang cukup handal pun bisa menerima EPA (Environmental Protection Agency) yang dapat mengambil alih fungsi penyelidikan, penyidikan dan penuntutan. ${ }^{5}$

Namun untuk konteks Indonesia persoalannya adalah masih adanya sementara kalangan seperti pihak kepolisian dan terutama kejaksaan yang mengkhawatirkan jika institusi super body semacam KPK dihadirkan dalam sistem penegakan hukum, maka akan mengakibatkan terjadinya tumpang tindih tugas

4Sekedar menyebutbeberapa contoh misalnya, Singapura telah memiliki Corruption Practices Investigation Bureau (CPIB) pada tahun 1952. Malaysia pun telah mempunyai Badan Pencegah Rasuah (BPR) tahun 1967. Sedangkan Hongkong juga sudah membentuk lembaga khusus serupa bemama Independent Comission Against Corruption (ICAC) pada 1974. Harian Jawa Pos, 9 Maret 2004.

${ }^{5}$ Romli Atmasasmita, "Latar Belakang Pembentukan Komisi Pemberantasan Tindak Pidana Korupsi di Indonesia" sebagaimana dikutip oleh Aloysius Wisnubroto, "Mengkritisi Rancangan Undang-Undang tentang Komisi Pemberantasan Tindak Pidana Korupsi", Makalah disampaikan pada Forum Diskusi llmiah Membahas RUU KPTPK, diselenggarakan oleh Fakultas Hukum Atmajaya Yogyakarta tanggal 3 November 2001. 
dan kewenangan (kinerja) di antara aparat. Hal ini pada akhirnya pun bukan mustahil akan dapat merusak sistem peradilan pidana Indonesia yang telah dibangun selama ini. Dalam konteks demikian, maka justifikasi kehadiran KPK memang tidak cukup jika hanya didasarkan pada legitimasi yang bersifat sosio-yuridis. Dalam arti karena ada kebutuhan sosial yang kemudian dikuatkan melalui keabsahan suatu undang-undang semata. Akan tetapi ia bahkan juga membutuhkan semacam faktor lapang dada dari kalangan aparat penegak hukum konvensional terutama kejaksaan. Karena secara psikologis institusi penuntut ini pasti merasa "terampas" atau setidaknya "terintervensi" tugas dan kewenangannya. ${ }^{6}$

Di samping itu, "potret buram" penegakan hukum terhadap kejahatan korupsi yang selama ini sering terlihat dan dirasakan oleh masyarakat, bukan mustahil telah melahirkan pesimisme publik terhadap upaya-upaya apapun yang dimaksudkan untuk memberantas korupsi. Tidak terkecuali upaya semacam menghadirkan KPK ini. ${ }^{7}$ Tentu yang paling mengkhawàtirkan adalah jika puncak dari segala pesimisme tersebut akhirnya melahirkan fenomena rakyat menjustifikasi atau setidaknya merestui korupsi itu sèndiri. ${ }^{8}$

:Berdasarkan paparan di atas, maka tulisan ini mencoba untuk mencermati melalui deskripsi analitis tentang apa urgensi dan justifikasi kehadiran lembaga KPK, kewenangan-kewenangan apa yang dimilikinya dan bagaimana implikasi dari penerapan kewenangan tersebut dalam konteks sistem peradilan pidana yang telah ada? Di samping itu, dalam rangka memperkuat dasar mengenai pentingnya kehadiran KPK, tulisan ini juga ingin mencermati berbagai ide yang relevan guna mengoptimalkan eksistensi dan peran lembaga tersebut di masa mendatang agar benar-benar berkorelasi dengan tujuan pokoknya yakni memberantas korupsi.

\section{Mermahami Urgensi Kehadiran KPK}

Dalam salah satu buti konsideran UU No. 30 Tahun 2002 tentang Komisi Pemberantasan Tindak Pidana Korupsi (KPTPK) atau disingkat $\mathrm{KPK}$, antara lain disebutkan bahwa dibentuknya komisi tersebut adalah karena di satu sisi realitas korupsi di Indonesia dinilai semakin memprihatinkan dan telah menimbulkan kerugian besar terhadap keuangan maupun

${ }^{8}$ Deskripsi dan prediksi secara lengkap mengenai hal di atas antara lain dapat dibaca analisis Badan Pengawasan Keuangan dan Pembangunan (BPKP) dalam buku Laporan Tahunannya, Strategi Pemberantasan Korupsi Nasional (Jakarta, BPKP, 1999), hlm. 223-225.

${ }^{7}$ Meskipun tidak secara spesifik mengkaitkan dengan kehadiran KPK, harian Kompas dalam edisi tanggal 12 Juni 2004 pernah mempublikasikan hasil polling masyarakat dengan poin pertanyaan antara lain: apakah anda menilai pemberantasan KKN di Indonesia selama ini berhasil dan bagaimana pandangan anda tentang hal tersebut di masa mendatang? Dengan responden berjumlah 990 orang, hasil polling menggambarkan bahwa $67,5 \%$ menyatakan tidak berhasil dan pesimis, $18,8 \%$ menilai berhasil dan optimis serta $13,7 \%$ menjawab tidak tahu pasti.

${ }^{8}$ Baca Viddy A.D. Daery, Mengapa Rakyat Kecil Restui Korupsi ? artikel pada harian Jawa Pos, edisi tanggal 8 Januari 2004. 
perekonomian negara sehingga menghambat pembangunan nasional dalam rangka mewujudkan kemakmuran, kesejahteraan dan keadilan masyarakat. Sementara itu pada sisi yang lain, upaya pemberantasan korupsi yang telah berjalan selama ini dinilai pula belum terlaksana secara optimal. Karena lembaga pemerintah (c.q aparat penegak hukum) yang bertugas menangani perkara tindak pidana korupsi dipandang belum dapat berfungsi secara efektif dan efisien. ${ }^{9}$

Berdasarkan hal di atas, dapat diketahui bahwa urgensi pembentukan KPK ialah untuk optimalisasi pemberantasan korupsi yang sulit diharapkan terwujudnya jika masih terus mengandalkan institusi penegak hukum konvensional yang telah ada.

$\mathrm{Hal}$ ini disebabkan karena pada kenyataannya aparat penegak hukum itu sendiri seringkali memang justru terlibat dalam praktek korupsi yang mereka tangani. ${ }^{10}$

Oleh karena itu sudah tepat jika dalam Penjelasan UU No.30/2002 ditegaskan bahwa kewenangan KPK yang antara lain dapat melakukan penyelidikan, penyidikan dan penuntutan terhadap kasus korupsi adalah khusus mengenai kasus korupsi yang: penyelenggara negara dan orang lain yang ada kaitannya dengan tindak pidana korupsi yang dilakukan oleh aparat penegak hukum atau penyelenggara negara;

b. mendapat perhatian yang meresahkan masyarakat dan / atau;

c. menyangkut kerugian negara paling sedikit Rp: 1.000 .000 .000 ,- (satu milyar rupiah)"

Dalam perspektif sistem peradilan pidana, adanya kewenangan KPK di atas ditambah dengan sejumlah besar kewenangan lain yang juga dimiliki, ${ }^{12}$ memang telah menempatkan lembaga ini pada posisi yang amat spesial sekaligus kontroversial. Karena KPK berwenang melakukan berbagai tindakan hukum yang selama ini hanya dapat dibenarkan jika dilakukan oleh aparat penegak hukum seperti kepolisian dan kejaksaan. Di samping itu, pada awal kehadirannya, KPK juga diberi legitimasi yuridis untuk "melikuidasi" keberadaan lembaga lain yang sebelumnya juga menjadi penunjang pemberantasan korupsi yaitu Komisi Pemeriksa Kekayaan Pejabat Negara (KPKPN Konsekuensinya, sejak KPK muncul maka KPKPN harus melebur diri dalam lembaga super body tersebut.

\section{a. melibatkan aparat penegak hukum,}

'Lihat bagian Menimbang (Konsideran) huruf a dan b UU No. 30 Tahun 2002 tentang Komisi Pemberantasan Tindak Pidana Korupsi.

${ }^{10}$ Sebagai contoh antara lain dapat disebutkan misalnya kasus pemberian suap dari tersangka Prayoga Pangestu yang diduga pernah diterima mantan Jaksa Agung Andi Ghalib saat menangani perkaranya, kasus rumah bermasalah milik Jaksa Agung M.A Rahman yang diduga hasil pemberian seorang tersangka suatu kasus korupsi saat Rahman masih menjabät di Kejaksaan Tinggi Jawa Timur, dan kasus-kasus mafia peradilan lainnya yang pada umumnya terasa kejadiannya namun sulit pembuktiannya.

"Lihat ketentuan Pasal 11 jo Penjelasan Umum Alenia ke 7 UU No. 30 Tahun 2002 tentang Komisi Pemberantasan Tindak Pidana Korupsi.

${ }^{12}$ Ketentuan selengkapnya mengenai tugas, wewenang dan kewajiban KPK dapat dilihat pada Pasal 6 15UU No. 30 Tahun 2002. Adapun uraian serta analisis mengenai hal ini selanjutnya akan dipaparkan secara khusus pada bagian depan. 
Walaupun sebelum "teriikuidasi", kinerja KPKPN sebenamya justru menunjukkan keberhasilan. Hal ini antara lain ditandai dengan kesuksesan KPKPN dalam mengungkap berbagai kasus kekayaan bermasalah dari sejumlah pejabat penting negara. Oleh karena itu tidak berlebihan jika kebijakan likuidasi KPKPN tersebut ditengarai sarat muatan politisnya. ${ }^{13}$

Dengan konfigurasi pemikiran di atas, dapat dipahami jika saat pertama kali KPK hadir telah mendapat sorotan tajam bahkan penolakan dari sebagian elemen publik. Tidak sedikit pihak yang berpandangan bahwa pembentukan KPK hanya merupakan cara pemerintah untuk menutupi kegagalan dan kekurang seriusan dalam memberantas korupsi. Keberadaan KPK sebenarnya hanya sebagai upaya penciptaan public image bahwa pemerintah masih berkomitmen untuk memberantas korupsi. Dengan demikian masyarakat masih dapat diharapkan untuk tetap memberikan respek dan simpati kepada eksistensi pemerintah.

Persepsi minor seperti ini tampaknya semakin memperoleh pembenaran jika dikaitkan dengan proses dan hasil akhir seleksi kepemimpinan KPK yang seolah telah "didesain" sebelumnya oleh kekuatan tertentu. Akibatnya yang muncul sebagai pemimpin KPK sebagian besar adalah orang-orang yang bukan termasuk harapan publik. ${ }^{14}$

Berbagai pandangan pesimis terhadap keberadaan KPK di atas, walaupun terkesan memvonis dan berlebihan akan tetapi memang tidak sepenuhnya keliru. Menghadirkan lembaga super body dengan tidak mempersiapkan secara matang mengenai struktur, infra struktur, sarana prasarana dan human resource-nya yang benarbenar handal dan bersih, dikhawatirkan hanya akan menambah daftar panjang tentang keberadaan lembaga-lembaga pemberantas korupsi yang sudah ada selama ini namun belum pernah memainkan peran yang berarti. Dalam kondisi demikian, eksistensi KPK tentu layak diragukan kemampuannya untuk dapat memberantas korupsi di Indonesia yang sudah demikian "sistemik dan membudaya". Meskipun kepadanya diberikan kewenangan besar. ${ }^{15}$

Penanggulangan kejahatan korupsi di Indonesia yang berada dalam situasi dan kondisi yang sudah menyentuh ke segala bidang kekuasaan baik eksekutif, legislatif maupun yudikatif ini, seharusnya memang tidak hanya selalu diupayakan dengan melalui pembentukan - lembaga-lembaga baru ataupun undang-undang baru. Sebab dari segi undang-undang misalnya, adanya Tap MPR No.XI/MPR/1998 tentang Penyelenggaraan Negara yang Bersih dan Bebas KKN yang kemudian dijabarkan penegasannya dalam UU No. 28 Tahun 1999 mengenai hal yang sama, demikian juga adanya UU No. 31 Tahun 1999 tentang Pemberantasan Tindak Pidana Korupsi yang kemudian diamandemen untuk disempumakan melalui UU No. 20 Tahun

${ }^{13}$ Analisis mengenai motiv dibalik likuidasi KPKPN ke dalam KPKdi atas, antara lain dapat dibaca M.Abdul Kholiq, "Likuidasi KPKPN sebagai Kebijakan yang Kontraproduktif", harian Kedaulatan Rakyat edisi tanggal 11 Desember 2002.

14 Lihat Mas Achmad Santosa, "Proses Seleksi Pernimpin KPK", artikel pada harian Koran Tempo, edisi tanggal 19 Desember 2003.

${ }^{15}$ Baca analisis Indiyanto Seno Adjie tentang kehadiran KPKdalam harian Kompas, 18. Desember 2003. 
2001, adalah sekedar contoh bahwa dasar yuridis yang diperlukan untuk memberantas korupsi sesungguhnya tidak ada kendala berarti.

Demikian juga dari sudut partisipasi publik. Tumbuhnya berbagai Lembaga Swadaya Masyarakat (LSM) seperti ICW, GOWA dan organisasi-organisasi massa lainnya seperti NU dan Muhammadiyah yang selalu menyuarakan against with corruption, sesungguhnya telah mencerminkan adanya faktor positif dari masyarakat yang seharusnya mampu melahirkan kinerja penegakan hukum terhadap korupsi secara optimal.

Jika kenyataannya tidak demikian, maka problem buruknya penegakan hukum terhadap korupsi di Indonesia patut diasumsikan bahwa hal itu tampaknya lebih merupakan persoalan minimnya sosok aparat penegak hukum yang benar-benar profesional dan berintegritas tinggi.

Banyak analisis menyebutkan bahwa di antara sekian macam faktor yang dapat mempengaruhi keberhasilan penegakan hukum, seperti aturan perundang-undangan, sarana prasarana, dukungan masyarakat, kebudayaan dan sebagainya, faktor aparatlah yang sesungguhnya paling memegang peranan penting. Sebab secara sosiologis, masyarakat biasanya cenderung hanya melihat dan selanjutnya menyimpulkan bahwa apa yang disebut hukum dan harus ditaati itu sebenarnya adalah berupa apa yang tercermin dari perilaku, kinerja dan integritas aparat pada saat menjalankan tugas-tugas penegakan hukum.

Jadi, baik buruknya potret hukum yang berupa ketentuan-ketentuan abstrak normatif ini, nyaris bergantung pada bagaimana hukum tersebut dikongkritkan oleh "tangan" aparat. Substansi hukum yang baik dapat melahirkan image buruk jika dipraktekkan oleh aparat yang buruk. Sebaliknya meskipun substansi suatu aturan hukum buruk atau kurang ideal, tetapi jika dipraktekkan oleh aparat yang profesional dan memiliki komitmen moral tinggi serta terpuji, maka hukum tersebut pun bukan mustahil dapat melahirkan kesan baik dan ketaatan publik yang tinggi. Barangkali dalam kontek demikian inilah letak relevansi sebuah pepatah yang sering kita dengar (walau tidak sepenuhnya benar) yang menyatakan bahwa the man behind the gun. Bahaya tidaknya senjata itu tergantung siapa yang memegangnya. Baik buruknya hukum itu juga lebih bergantung pada siapa yang menjadi pelaksananya. ${ }^{16}$

Dalam konteks korupsi, isu mafia peradilan yang terus menerpa aparat penegak hukum selama ini, tampaknya cukup menjadi gambaran bagi ketidak mampuan sekaligus ketidak mauan mereka untuk menyadari posisi pentingnya. Akibatnya, selain tidak kredibel aparat penegak hukum sekarang juga telah kehilangan legitimasinya baik di mata rakyat secara nasional maupun dalam pandangan komunitas internasional. ${ }^{17}$

${ }^{18}$ Masalah peran penting aparat dalam konteks keberhasilan penegakan hukum di atas, antara lain dapat dibaca pada Soerjono Soekanto, Faktor-Faktor Yang Mempenganhi Penegakan Hukum (Jakarta: Rajawali Press, 1983), hlm. 4. Lihat juga pendapat Abdul Kariem Nasution, "Masalah Penegakan Hukum", Kumpulan Makalah Hasil Simposium yang diedit oleh Badan Pembinaan Hukum Nasional (BPHN) (Jakarta: Bina Cipta, 1979), hlm. 45

17 Artidjo Al-Kostar, Masalah Mafia Peradilan dan Penanggulangannya, artikel pada Jumal Hukum edisi No.21 Volume 9 Tahun 2002, hlm.3-4. 
Dalam perspektif teori, Baharudin Lopa pernah menyatakan bahwa setidaknya ada tiga syarat bagi keberhasilan penegakan hukm yeng optinal Pertama, ialah adanya peraturan hukum (perundang-undangan) yang memadai dan sesuai dengan aspirasi masyarakat. Kedua, adanya aparat penegak hukum yang profesional dan bermental tangguh atau memiliki integritas moral yang terpuji. Dan ketiga ialah adanya kesadaran hukum masyarakat yang memungkinkan sekaligus mendukung dilaksanakannya penegakan hukum. ${ }^{18}$

Kerangka pikir di atas tampaknya tepat untuk dijadikan dasar memahami lemahnya penegakan hukum korupsi ini. Artinya, jika syarat harus adanya hukum dan dorongan publik yang dibutuhkan bagi pemberantasan korupsi di Indonesia sebagaimana telah diuraikan terdahulu, pada prinsipnya dipandang tidak ada masalah alias sudah cukup memadai, maka hal ini menunjukan bahwa faktor aparat penegak hukumlah yang tampaknya harus dicermati sebagai sumber problema.

Ada dua hal yang patut dianalisis dalam konteks ini. Pertama adalah telah terjadinya delegitimasi sosial atas keberadaan dan peran aparat penegak hukum yang diakibatkan oleh relatif buruknya kinerja mereka dalam menangani berbagai kasus penting korupsi selama ini. Hal ini tentu memerlukan alternatif solusi yang lebih bersifat penggantian peran kelembagaan agar tidak terjadi kevakuman kinerja penegakan hukum akibat delegitimasi tadi.

Kedua, posisi struktural kepolisian yang berpuncak pada Kapolri maupun kejaksaan yang berpuncak pada institusi Jaksa Agung yang berada di bawah eksekutif (c.q Presiden), tampaknya juga menjadi faktor penghambat yang signifikan bagi optimalisasi penegakan hukum. Sebab dalam kedudukan demikian, dapat diprediksikan bahwa mereka akan mudah mengalami intervensi kekuasaan eksternal sehingga akhirnya cenderung mempraktekkan apa yang disebut sebagai penegakan hukum diskriminatif atau pilihpilih. Terutama jika menghadapi kasus korupsi dengan tersangka pelaku seorang pejabat negara. ${ }^{19}$

Dalam konteks demikian, wajar bila belakangan ini banyak bermunculan pandangan yang menghendaki agar aparat penegak hukum terutama institusi Jaksa Agung yang mempunyai tugas khusus penuntutan terhadap kejahatan korupsi, dijadikan lembaga negara yang independen dalam melaksanakan kekuasaan yudikatif di bidang penuntutan tertinggi pada perkara pidana. Selama kejaksaan secara kelembagaan masih di bawah pemerintah maka seorang Jaksa Agung selalu dimasukkan dalam daftar kabinet pemerintahan, maka selama itu pula kinerja kejaksaan terutama dalam memberantas korupsi akan sangat bergantung pada kemauan atasannya

${ }^{18}$ Baharudin Lopa, Permasalahan Pembinaan dan Penegakan Hukum di Indonesia. (Jakarta: Bulan Bintang, 1987), hlm. 3-4.

${ }^{18}$ Konstruksi teoritik untuk memahami realitas penegakan hukum diskriminatif tersebut antara lain dapat dibaca pada tulisan Sațipto Rahardjo, IImu Hukum (Bandung: Alumni, 1982), him. 166-167. Lihatjuga Sudjito, Penegakan Hukum: Akar Permasalahan dan Altematif Solusinya, artikel dalam Jurnal Mimbar-Hukum (Yogyakarta: Fakultas Hukum, UGM, edisi Januari 2004). 
(pemerintah /penguasa. ${ }^{20}$ Bahkan penegasan yuridis dalam Pasal 19 UU No. 5 Tahun 1991 tentang Kejaksaan yang menyatakan bahwa Jaksa Agung diangkat dan diberhentikan serta bertanggung jawab kepada Presiden dapat melahirkan implikasi berupa sikap jajaran kejaksaan yang akhimya harus menunjukkan loyalitas kepada Presiden. Jika seorang Presiden merupakan hasil dukungan dari berbagai kepentingan politik tertentu baik yang bersifat kelembagaan seperti partai, ormas maupun kekuatan perseorangan, maka sangat logis jika Jaksa Agung yang dipilih Presiden tersebut akhirnya harus memilih "komitmen" untuk kepentingan politik tertentu pula. ${ }^{21}$

Berdasarkan hal-hal di atas, dapat ditegaskan bahwa pemberantasan korupsi yang efektif dan efisien tampaknya memang tidak bisa sepenuhnya diandalkan pada eksistensi dan peran lembaga penegak hukum konvensional yang telah ada. Sebab selain mereka mengalami kendala ketidak mandirian secara struktural kelembagaan, dalam praktek mereka juga seringkali menampilkan potret penegakan hukum yang diskriminatif, koruptif dan unlegitimate di mata masyarakat.

Oleh karena itu kiranya dapat dipahami jika akhirnya muncul gagasan untuk melahirkan institusi baru yang mampu merespon .problem stagnasi penegakan hukum korupsi di atas. Lembaga baru tersebut sekarang telah terwujud yakni dengan terbentuknya Komisi Pemberantasan Tindak Pidana Korupsi (KPTPK) atau sering disingkat KPK. Dalam UU No. 30 Tahun 2002, selain ada penegasan tentang independensi, ${ }^{22}$ komisi ini juga dinyatakan memiliki berbagai tugas dan kewenangan yang memang sangat dibutuhkan untuk optimalisasi pemberantasan korupsi.

\section{Tugas dan Wewenang KPK dalam Peradilan Korupsi}

Menurut ketentuan Pasal 6 UU No. 30 Tahun 2002, KPK dinyatakan memiliki tugastugas sebagai berikut:

a. melakukan koordinasi dengan instansi yang berwenang melakukan pemberantasan tindak pidana korupsi;

b. melakukan supervisi terhadap instansi yang . berwenang melakukan pemberantasan tindak pidana korupsi;

c. melakukan penyelidikan, penyidikan dan penuntutan terhadap tindak pidana korupsi;

d. melakukan tindakan-tindakan pencegahan terhadap tindak pidana korupsi; dan

e. melakukan monitor terhadap penyelenggaraan pemerintahan negara.

${ }^{20}$ Baca pandangan Danang Widoyoko, Wakil Koordinator Indonesia Cornption Watch (ICW), "Perlukah Jaksa Agung Non Karier?" harian Republika edisi tanggal 5 Juli 2004. Lihat pula tulisan Indriyanto Seno Adjie, "Kejaksaan Agung dan Eksistensi Konstitusional", artikel dalam harian Kompas edisi tanggal 22 Juni 2004.

21 Daniel J. Meador, "The President, The Attomey General and The Department of Justice" sebagaimana dikutip oleh Bayu Wicaksono, "Mencari Sosok Jaksa Agung", harian Kompas edisi tanggal 22 juni 2004.

22 Dalam Penjelsan Umum Alenia ke 11 UU No. 30 Tahun 2002 ditegaskan secara eksplisit bahwa Komisi Pemberantasan Korupsi merupakan lembaga negara yang bersifat independen yang dalam melaksanakan tugas dan wewenangnya bebas dari kekuasaan manapun. 
Untuk menurijang pelaksanaän tugastugas tersebut, KPK memiliki kewenangankewenangan hukum sebagaimana ditentukan dalam Pasal 7, 8, 12, 13 dan 14 UU No. 30 Tahun 2002 yang pada pokoknya meliputi halhal berupa:

a. mengkoordinasikan langkah-langkah penyelidikan, penyidikan dan penuntutan terhadap suatu perkara korupsi yang masuk dalam lingkup tugasnya (berdasar Pasal 11) dengan instansi lain yang terkait;

b. menetapkan sistem pelaporan dalam kegiatan pemberantasan korupsi;

c. meminta informasi tentang kegiatan pemberantasan korupsi kepada instansi yang terkait;

d. meminta laporan instansi terkait mengenai langkah-langkah pencegahan tindak pidana korupsi;

e. melakukan pengawasan, penelitian dan penelaahan terhadap instansi yang - menjalankan tugas dan wewenangnya dalam pemberantasan korupsi;

f. karena alasan-alasan tertentu, KPK dapat mengambil alih penyelidikan atau penuntutan terhadap suatu perkara korupsi yang berada dalam lingkup tugasnya, sekalipun sedang ditangani oleh kepolisian atau kejaksaan.23.

Di samping itu, KPK juga masih memiliki wewenang lain yang merupakan hak istimewa di antaranya ialah:

a. melakukan penyadapan pembicaraan melalui telepon dan merekamnya;

b. memerintahkan kepada instansi lain yang terkait (c.q keimigrasian) untuk melarang seseorang bepergian ke luar negeri;

c. meminta keterangan -pada bank mengenai rekening seseorang yang diduga berkait dengan suatu perkara korupsi dan sekaligus memerintahkan pemblokiran jika dipandang perlu;

d. memerintahkan kepada 'pimpinan atau atasan tersangka suatu perkara korupsi untuk memberhentikan sementara dari jabatannya;

e. meminta bantuan kepolisian atau instansi lain terkait untuk melakukan penangkapan, penahanan, penggeledahan dan penyitaan dalam perkara tindak pidana korupsi yang sedang ditangani. ${ }^{24}$

Selain memiliki kewenangan, untuk menciptakan check and balance serta kontrol terhadap kinerja lembaga, KPK juga dibebani kewajiban oleh undang-undang sebagaimana ditegaskan dalam Pasal. 15 antara lain yaitu:

a. memberikan perlindungan terhadap saksi atau pelapor yang turut mengungkap suatu perkara korupsi;

b. memberikan informasi atau bantuan untuk

${ }^{23}$ Berdasarkan Pasal 9, kewenangan KPKuntuk dapat melakukan tugas supervisi atau mengambil alih tindakan penyelidikan maupun penuntutan suatu perkarakorupsi yang sedang ditangani kepolisian atau kejaksaan di atas harus didasarkan pada alasan-alasan bahwa penanganan perkara korupsi tersebut: (a) berlarut-larut tanpa alasan; (b) tidak diteruskan (dihentikan prosesnya) tanpa dasar yuridis; (c) ada indikasi untuk melindungi pelaku korupsi yang sesungguhnya; (d) ada indikasi terjadi campur tangan oleh eksekutif, yudikatif atau legislatif dan (e) kepolisian atau kejaksaan tidak sanggup lagi melanjutkan proses perkara tersebut karena suatu keadaan atau pertimbangan tertentu.

24 Mengenai wewenang khusus atau hak istimewa KPK di atas, selengkapnya dapat dibaca pada ketentuan Pasal 12 UU No. 30 Tahun 2002. 
memperoleh data mengenai penanganan kasus korupsi kepada masyarakat yang memerlukan;

c. menyusun laporan tahurian tentang pelaksanaan tugas dan kewajibannya kepada Presiden, DPR dan Badan Pemeriksa Keuangan.

Dari deskripsi tentang besarnya cakupan tugas dan kewenangan KPK tersebut, tampak bahwa komisi ini memang merupakan lembaga khusus yang bersifat sebagai super body. Sebab pada umumnya, tugas dan kewenangan sebuah komisi hukum setelah menjalankan kinerjanya maksimal hanya dapat memberikan seruan atau rekomendasi untuk langkah-langkah hukum-berikutnya yang harus ditindak lanjuti-oleh institusi lain yang terkait. ${ }^{25}$

Namun berdasarkan ketentuan UU No. 30 Tahun 2002, komisi bernama KPK ini ternyata dilegitimasi pula untuk dapat melakukan tindakan hukum isemacam "mengintervensi"- terhadap kèwenangan menyidik atau menuntut yang dimiliki oleh instansi penegak hukum yang sebelumnya telah ada (c:q kepolisian dan kejaksaan Walaupun dengan beberapa persyaratan. tertentu.

Keterlibtan KPK dalam penyelesaian suatu perkara korupsi, tidaklah sekedar bersifat membantu aparat penyidik seperti kedudukan Penyidik Pegawai Negeri Sipil (PPNS) yang dikenal dalam Kitab Undang-Undang Hukum Acara Pidana (KUHAP). Komisi ini seperti telah diuraikan di atas, memiliki wewenang sampai pada bentuk melakukan koordinasi bahkan - supervisi (mengambil alih) penanganan suatu kasus korupsi yang sedang berjalan/ditangani. oleh kepolisian atau kejaksaan.

Pemberian wewenang hukum kepada KPK seperti ini; memang dikhawatirkan dapat melahirkan masalah tumpang tindih tugas dan kewenangan (baca: "perebutan kompetensi") dengan aparat lain. Ada beberapa argumentasi yang meridasari kekhawatiran tersebut, yaitu:

1. Dilihat dari segi konsep tentang Sistem $\therefore$ Peradilan Pidana (Criminal Justice System) atau SP.P, distribusi masing-masing subsistem yang ada dalam SPP sebenarnya sudah jelas yaitu bahwa - kepolisian melakukan fungsi penyelidikan dan penyidikan, kejaksaan melakukan fungsi 'penuntutan dan kehakiman melakukan fungsi peradilan/mengadili. ${ }^{26}$ Jika sekarang KPK ditugasi pula untuk melaksanakan fungsi penyelidikan,

${ }^{25}$ Sebagai contoh misalnya dapat dicermati ketentuan UU No. 26 Tahun 2000 tentang Pengadilan HAM yang menegaskan bahwa Komisi Nasional Hak Asasi Manusia (KOMNAS-HAM) hanya bertugas mengungkap indikator tentang telah terjadinya pelanggaran HAM Berat pada suatu kasus pidana melalui tindakan penyelidikan. Selanjutnya hasil penyelidikan tersebut akan direkomendasikan untuk ditindak lanjuti melalüi tindakan penyidikan maupun penuntutan kepada Kejaksaan Agung. Jadi langkah-langkah hụkum selanjutnya tidak diteruskan sendiri oleh Komnas HAM.

.. 26. Secara yuridis konsep tentang Criminal Justice System beserta fungsi-fungsi yang harus dilakukan oleh berbagai sub sistem yang ada di dalamnya telah digariskan prinsip-prinsipnya dalam UU No. 8 Tahun 1981 tentang KUHAP. Uraian lebih detil mengenai hal ini antara lain dapat dibaca M. Yahya Harahap, Pembahasan Permasalahan dan Penerapan KUHAP, Edisi Kedua (Jakarta: Sinar Grafika, 2000), him. 89-98. 
penyidikan dan penuntutan, maka kekhawatiran tentang terjadinya benturan kewenangan tersebut sulit dihindari.

2. Dilihat dari segi dasar hukum, antara kepolisian, kejaksaan dan KPK sesungguhnya sama-sama memiliki landasan yuridis yang merupakan hukum positif untuk melakukan tugas sesuai dengan fungsi masing-masing dalam penanganan perkara korupsi. ${ }^{27}$ Jadi wajar jika kehadiran KPKdengan fungsi yang samá seperti lembaga kepolisian dan kejaksaan dikhawatirkan akan melahirkan tumpang tindih fungsionalisasi kelembagaan.

3. Dilihat dari segi struktural kelembagaan, kepolisian dan kejaksaan sama sekali tidak memiliki hubungan hirarkhis dengan KPK. Jika KPK menerapkan wewenangnya untuk melakukan koordinasi apalagi supervisi dalam penanganan suatu perkara korupsi, maka hal ini tentu menimbulkan kesan bahwa seolah-olah kepolisian dan kejaksaan berada di bawah KPK.

4. Dilihat dari segi sosio kultural, pemberian wewenang kepada KPK untuk melakukan koordinasi terutama supervisi dari aparat lain yang terkait dalam penanganan perkara korupsi, akan mudah melahirkan kesan bahwa instansi yang tugasnya disupervisi oleh KPK merupakan lembaga yang berkondite buruk. Akhimya, bukan mustahil hal seperti ini dapat melahirkan problem "harga diri" dari instansi yang bersangkutan. Jika sudah demikian, maka tidak tertutup kemungkinan kinerja KPK dalam memberantas korupsi akan "menuai" implikasi berupa kendalakendala non kooperatif dari kalangan penegak hukum konvensional tersebut.

Berdasar konsep pemikiran di atas, maka wewenang besar yang dimiliki KPK dan dikhawatirkan dapat menimbulkan "benturan" dengan aparat penegak hukum lain, selintas memang benar. Terlebih lagi jika implementasi wewenang KPK tersebut berlaku secara umum tanpa ada batasan. Artinya dapat diterapkan untuk penanganan semua perkara pidana atau setidaknya terhadap semua perkara korupsi.

Akan tetapi, dalam Pasal 9 jo Pasal 11 UU No. 30 Tahun 2002 telah ditegaskan bahwa tugas dan wewenang KPK yang "ekstra" tersebut hanya boleh diterapkan untuk menangani kasus korupsi yang ditengarai melibatkan aparat penegak hukum atau penyelenggara negara yang berkait dengan dugaan korupsi oleh aparat penegak hukum, bersifat meresahkan masyarakat atau setidaknya mendapat perhatian publik dan menyangkut prediksi kerugian negara minimal satu milyar rupiah. Jadi bersifat sangat limitatif. Itupun dengan persyaratan yaitu apabila kepolisian dan kejaksaan berdasarkan indikasi

${ }^{27}$ Sejak UU No. 5 Tahun 1991 tentang Kejaksaan disahkan, institusi ini ditetapkan sebagai penyidikutama sekaligus penuntut perkara korupsi. Akan tetapi mengingat UU No. 8 Tahun 1981 tentang KUHAP sebelumnya telah menetapkan bahwa Polri merupakan penyidik perkara pidana, maka agar tidak terjadi benturan UU No. 5 Tahun 1991 memposisikan kejaksaan sebagai koordinator penyidikan dalam penanganan perkara korupsi. Hal ini juga ditegaskan kembali oleh ketentuan Pasal 27 UU No. 31 Tahun 1999 tentang Pemberantasan Tindak Pidana Korupsi. Sementara itu wewenang yang sama untuk melakukan penyelidikan, penyidikan dan penuntutan terhadap perkara korupsi bagi KPKjuga ditegaskan legitimasinya dalam UU No. 30 Tahun 2002. Lihatkembali ketentuan Pasal 6 UU No. 30 Tahun 2002. 
tertentu patut dinilai tidak dapat menjalankan fungsinya, baik karena tidak mampu atau tidak serius atau memang tidak punya kehendak sama sekali dalam menindak lanjuti laporan atau pengaduan terhadap dugaan terjadinya suatu tindak pidana korupsi.

Dengan analisis di atas dapat ditegaskan bahwa kekhawatiran mengenai terjadinya perebutan kompetensi atau benturan kinerja berdasarkan wewenang antara aparat kepolisian dan kejaksaan dengan ịstitusi KPK adalah tidak beralasan. Karena untuk menangani perkara pidana secara umum ataupun perkara korupsi secara khusus (kecuali kasus korupsi yang kriterianya sesuai Pasal 11 UU No. 30 Tahun 2002), pada prinsipnya polisi masih tetap memiliki wewenang sebagai penyelidik dan penyidik serta jaksa pun masih pempunyai wewenang sebagai penuntut. Jadi tidak ada dupilaksi kewenangan sama sekali dan dengan demikian pula maka kehadiran KPK tidak dapat ditafsir sebagai perusak sistem peradilan pidana Indonesia. Oleh karena itu jaminan mengenai hal inipun ditegaskan dalam Penjelasan Umum Alenia ke 6 UU No. 30 Tahun 2002 yang menyatakan pengaturan. kewenagan KPK dalam undang-undang ini dilakukan secara berhati-hati agar tidak terjadi tumpang tindih kewenangan dengan berbagai instansi lain terkait.

Di samping itu, jika dicermati legal spirit yang terkadung dibalik ketentuan normatif Pasal 9 jo Pasal 11 di atas, justru terlihat bahwa eksistensi KPK sesungguhnya sangat penting dan strategis yakni sebagai pemicu untuk memberdayakan institusi yang telah ada dalam pemberantasan korupsi (trigger mechanism. Sasaran akhirnya ialah agar aparat penegak hukum yang telah ada tersebut (c.q kepolisian dan kejaksaan) dapat kembali menunjukkan kinerja yang profesional dengan landasan integritas moral sehingga dapat diperoleh suatu hasil penegakan hukum terhadap korupsi yang optimal. Selanjutnya dengan kondisi yang demikian tentu dapat diharapkan kembalinya kepercayaan publik terhadap hukum dan institusi penegaknya (tegaknya supremasi hukum Jadi sekali lagi, kehadiran KPK sama sekali bukan dimaksudkan untuk memonopoli tugas dan wewenang penyelidikan, penyidikan dan penuntutan. Apalagi mengambil alih secara absolut. ${ }^{28}$

Legal spirit yang mendasari fungsi kehadiran KPK yang berpuncak pada tujuan supremasi hukum tersebut tentu hans disadari dan didukung oleh siapapun (publik) terutama aparat kepolisian dan kejaksaan. Sebab hanya dengan itu eksistensi KPK dapat benar-benar memiliki legitimasi baik secara yuridis maupun sosiologis dan tidak perlu harus mengalami kendala-kendala non kooperatif dalam menjalankan tugas dan wewenangnya. Dalam hubungan ini Romli Atmasasmita pernah mengingatkan bahwa polemik soal tugas dan wewenang KPK haruslah segera dihentikan. Sejak UU No. 30 Tahun 2002 disahkan, siapapun termasuk pejabat eksekutif, legislatif maupun yudikatif tidak sepatutnya bekerja hanya dengan terus menerus mempermasalahkan

${ }^{28}$ Lihat Penjelasan Umum Alenia ke 8 Angka 2 dan 3 UU No. 30/2002 tentang Komisi Pemberantasan Tindak Pidana Korupsi. 
wewenang KPK apalagi mempolitisasinya. Sebab masalah korupsi adalah masalah hukum, bukan masalah politik di mana pemberantasannya tentu tidak dapat dikembalikan kepada otoritas politik. Yang sesungguhnya diperlukan sekarang ialah bagaimana publik memperlihatkan dukungannya terhadap kehadiran KPK sebagai salah satu bukti komitmen memerangi korupsi sambil terus menerus tetap memantau kinerja komisi super body ini. ${ }^{29}$

Selanjutnya untuk ke depan, persoalan sekaligus tantangan yang dihadapi KPK ialah bagaimana seharusnya komisi ini merealisasikan tujuan dan fungsi kehadirannya tersebut? Jawaban riil atas pertanyaan yang demikian menjadi penting mengingat citra penegakan hukum terhadap korupsi oleh aparat yang ada selama ini sudah terlanjur negatif dan melahirkan pesimisme publik. Sehingga sekalipun diberikan wewenang besar, eksistensi dan wibawa KPK di mata publik bukan mustahil akan dipandang sama dengan keberadaan lembaga-lembaga penegak hukum sebelumnya.

Dalam konteks di atas, Scott M. Davis menjelaskan melalui pandangannya yang dikenal dengan "Positioning Theory". Intinya, jika KPK sungguh-sungguh berkehendak menjadi lembaga yang legitimate sekaligus berwibawa dan disegani publik dalam memberantas konupsi, maka ia harus mampu membangun positioning.yaitu gabungan seni dan ilmu serta kinerja untuk melekatkan suatu citra "produk" atau ide pada pemikiran masyarakat yang mampu membedakan dirinya dengen posisipesaingrya. ${ }^{30}$

Dikaitkan dengan tantangan yang dihadapi KPK, maka konsep positioning tersebut dapat dilihat dari dua dimensi, yaitu posisi saat ini (current positioning) dan posisi yang diinginkan (desire positioning). Sejak awal kehadiran, KPK telah menetapkan posisi yang dinginkan sebagaimana terlihat pada visi dan misinya yakni mewujudkan Indonesia yang bebas korupsi dan menjadikan diri sebagai lembaga penggerak atau motor perubahan untuk mewujudkan bangsa Indonesia sebagai masyarakat anti korupsi. ${ }^{31}$

Namun desire positioning tersebut oleh publik tampaknya masih dipandang sebatas utopia. Sebab posisi KPK saat ini (sebagai lembaga yang baru terbentuk dan dengan kinerja yang belum memperlihatkan hasil), oleh publik akan mudah disetarakan dengan posisi lembaga penegak hukum lain sebelumnya yang terlanjur bercitra negatif tadi. Dalam kondisi demikian maka KPK tidak bisa tidak harus bekerja keras melalui praktekpraktek pemberantasan korupsi tanpa kompromi sesuai dengan tugas dan kewenangannya untuk merubah current posi-

\footnotetext{
29 Romli Atmasasmita, "Kinerja dan Tantangan KPK", harian Kompás edisi tanggal 17 Juli 2004.

${ }^{30}$ ScottM. Davis, "Brand Asset Management" sebagaimana dikutip oleh Sunarto Prayitno, Mempertanyakan Kredibilitas KPK, harian Kompas, edisi tanggal 13 Juli 2004.

${ }^{31}$ Secara tersirat (implisit) visi dan misi KPK ini dapat dilihat kembali pada Konsideran dan Penjelasan Umum UU No. 30 Tahun 2002 tentang Komisi Pemberantasan Tindak Pidana Korupsi
} 
tioning yang negatif menuju desire positioning yang benar-benar menjadi kenyataan. Dengan kata lain, untuk merubah posisi dalam pandangan publik, KPK memang harus memberikan bukti, bukan sekedar janji.

\section{Simpulan}

Berdasarkan deskripsi tentang keberadaan Komisi Pemberantasan Korupsi (KPK) dalam peradilan korupsi di Indonesia beserta pemasalahannya sebagaimana telah diuraikan di atas, kiranya dapat ditegaskan beberapa kesimpulan sebagai berikut:

1. Eksistensi KPK berdasarkan UU No. 30 Tahun 2002 adalah dimaksudkan sebagai lembaga super body yang bersifat khusus untuk mengoptimalkan pemberantasan korupsi di Indonesia. Kekhususan tersebut antara lain dapat dilihat dari besamya tugas dan wewenang KPK yang melampaui umumnya sebuah komisi, yaitu dimulai dari prevensi, represi, koordinasi hingga supervisi terhadap kewenangan instutusi lain dalam memberantas korupsi.

2. Ada dua background penting yang relevan untuk memahami urgensi kehadiran KPK. Pertama, karena institusi penegak hukum yang telah ada (c.q kepolisian dan kejaksaan) secara kelembagaan mengalami ketidakmandirian akibat posisi strukturalnya yang berada di bawah eksekutif (c.q Presiden Kedua, praktek penegakan hukum terhadap kejahatan korupsi oleh kedua institusi tersebut selama ini cenderung memperlihatkan ketidakseriusan dalam arti tidak efektif, efisien dan optimal serta telah melahirkan pesimisme publik tentang supremasi hukum khususnya di bidang pemberantasan korupsi.

3. Kehadiran KPK dengan tugas dan wewenang spesial seperti melakukan koordinasi dan supervisi terhadap fungsifungsi penyelidikan, penyidikan atau penuntutan yang seharusnya dijalankan oleh institusi kepolisian dan kejaksaan, tidak akan melahirkan tumpang tindih kenerja di antara lembaga-lembaga tersebut dan sekaligus juga tidak merusak sistem peradilan pidana yang ada. Sebab tugas dan wewenang KPK tersebut hanya boleh diimplementasikan pada penanganan kasus-kasus korupsi tertentu (limitatif) yang berdasarkan indikasi tertentu dapat disimpulkan bahwa aparat dari kedua institusi tersebut tidak mau atau tidak mampu menjalankan fungsi-fungsinya.

4. Untuk menumbuhkan kepercayaan publik sekaligus kewibawaan KPK sendir sebagai institusi harapan untuk menjadikan Indonesia yang benar-benar bersih dari korupsi, tidak ada jalan lain kecuali KPK ke depan harus terus menerus mempraktekkan pemberantasan korupsi tanpa kompromi namun tetap sesuai dengan tugas dan wewenang yang diberikan oleh undangundang.

\section{Daftar Pustaka}

Adjie, Indriyanto Seno, "Kejaksaan Agung dan Eksistensi Konstitusional", harian Kompas edisi tanggal 22 juni 2004.

Alkostar, Artidjo, "Masalah Mafia Peradilan dan Penanggulangannya", Jurnal Hukum, Fakultas Hukum UII, Yogyakarta, Edisi No. 21 Volume 9 Tahun 2002.

Ätmasasmita, "Romli, Kinerja dan Tantangan 
$\mathrm{KPK}^{\mathrm{n}}$, harian Kompas, edisi tanggal 17 Juli 2004.

Badan Pengawasan Keuangan dan Pembangunan (BPKP), Strategi Pemberantasan Korupsi Nasional, Jakarta: BPKP, 1999.

Daery, Viddy A.D, “Mengapa Rakyat Kecil Restui Korupsi?" harian Jawa Pos edisi tanggal 8 Januari 2004.

Harahap, M. Yahya, Pembahasan Permasalahan dan Penerapan KUHAP, Jakarta: Sinar Grafika, 2000.

Kholiq, M. Abdul, “Asas Pembuktian Terbalik dalam Penyelesaian Kasus Kejahatan Korupsi", Jurnal Hukum, Fakultas Hukum UII, Yogyakarta, Edisi No. 20 Volume 9 Tahun 2002.

Kholiq, M. Abdul, "Likuidasi KPKPN sebagai Kebijakan yang Kontraproduktif", harian Kedaulatan Rakyat, edisi tanggal 11 Desember 2002.

Lopa, Baharudin, Permasalahan Pembinaan dan Penegakan Hukum di Indonesia, Jakarta: Bulan Bintang, 1987.

Masduki, Teten, "Retorika Antikorupsi Capres", harian Kompas edisi tanggal 12 Juni 2004.

Nasution, Abdul Kariem, "Masalah Penegakan Hukum", Kumpulan Makalah Hasil Simposium tentang Penegakan Hukum, Jakarta:Bina Cipta, 1979.

Prayitno, Sunarto, "Mempertanyakan Kredibilitas KPK", harian Kompas edisi tanggal 13 Juli 2004.

Rahardjo, Satjipto, IImu Hukum, Bandung:
Alumni, 1982.

Santosa, Mas Achmad, "Proses Seleksi Pinpinan KPK", harian Koran Tempo edisi tanggal 19 Desember 2003.

Soekanto, Soerjono, Faktor-Faktor Yang Mempengaruhi Penegakan Hukum, Jakarta: Rajawali Press, 1983.

Sudjito, "Penegakan Hukum: Akar Permasalahan dan Alternatif Solusinya", Jurnal Mimbar Hukum, Fakultas Hukum UGM, Yogyakarta, Edisi Bulan Januari 2004.

Wicaksono, Bayu, "Mencari Sosok Jaksa Agung", harian Kompas edisi tanggal 22 Juni 2004.

Widoyoko, Danang, "Perlukah Jaksa Agung Non Karier", harian Republika edisi tanggal 5 Juli 2004.

Wisnubroto, Aloysius, "Mengkritisi Rancangan

Undang-Undang tentang Komisi Pemberantasan Tindak Pidana Korupsi", Makalah disampaikan pada Forum Diskusi IImiah berthema Membahas RUU KPTPK, Diselenggarakan oleh Fakultas Hụkum, Universitas Atma Jaya, . Yogyakarta, Tanggal 3 Nopember 2001.

UU No. 8 Tahun 1981 tentang KUHAP

Ư No. 5 Tahun 1991 tentang Kejaksaan

UU No. '31 Tahun 1999 tentang Pemberantasan Tindak Pidana Korupsi

UU No. 20 Tahun 2001 tentang Amandemen terhadap UU No. 31/1999

UU No. 30 Tahun 2002 tentang Komisi 
Pemberantasan Tindak Pidana Korupsi

UU No. 26 Tahun 2000 tentang Pengadilan
Hak Asasi Manusià

Harian Jawa Pos edisi 9 Maret 2004

Harian Kompas edisi 12 Juni 2004 םםם 